\title{
Protein kinase A mediates microglial activation induced by plasminogen and gangliosides
}

\author{
Kyoung-Jin Min ${ }^{1,2,3}$, Myung-Soon Yang ${ }^{1,2,3}$, \\ Ilo $\mathrm{Jou}^{1}$ and Eun-hye Joe $\mathrm{e}^{1,2,3,4}$ \\ ${ }^{1}$ Department of Pharmacology \\ ${ }^{2}$ Neuroscience Graduate Program \\ ${ }^{3}$ Brain Disease Research Center \\ Ajou University School of Medicine \\ Suwon 442-721, Korea \\ ${ }^{4}$ Corresponding author: Tel, 82-31-219-5062; \\ Fax, 82-31-219-5069; E-mail, ehjoe@madang.ajou.ac.kr
}

Accepted 23 September 2004

Abbreviations: CRE, CAMP response element; IL-1 $\beta$, interleukin$1 \beta$; iNOS, inducible nitric oxide synthase; NF-kB, nuclear factor-kappa $B$; PKA, protein kinase $A$; TNF- $\alpha$, tumor necrosis factor- $\alpha$

\begin{abstract}
In the injured brain, microglia is known to be activated and produce proinflammatory mediators such as interleukin-1 $\beta$ (IL-1 $\beta$ ), tumor necrosis factor $\alpha$ (TNF- $\alpha$ ) and inducible nitric oxide synthase (iNOS). We investigated the role of protein kinase $A$ (PKA) in microglial activation by both plasminogen and gangliosides in rat primary microglia and in the BV2 immortalized murine microglial cell line. Both plasminogen and gangliosides induced IL-1 $\beta$, TNF- $\alpha$ and iNOS mRNA expression, and that this expression was inhibited by the addition of the PKA inhibitors, KT5720 and H89. Both plasminogen and gangliosides activated PKA and increased the DNA binding activity of the CAMP response elementbinding protein (CREB). Furthermore, KT5720 and $\mathrm{H} 89$ reduced the DNA binding activities of CREB and NF-KB in plasminogen-treated cells. These results suggest that PKA plays an important role in plasminogen and gangliosidesinduced microglial activation.
\end{abstract}

Keywords: brain inflammation; cAMP response element binding protein (CREB); gangliosides; microglia; plasminogen; protein kinase $A$

\section{Introduction}

Microglia is major immune effector cells in the central nervous system. Microglial activation is a common phenomenon that occurs when the brain is injured (Woodroofe et al., 1986; Giulian et al., 1991). Activated microglia express inducible nitric oxide synthase (iNOS), cyclooxygenase-2 (COX-2) and the pro-inflammatory cytokines, interleukin-1 $\beta$ (IL-1 $\beta$ ) and tumor necrosis factor- $\alpha$ (TNF- $\alpha$ ) (Giulian et al., 1986; Zielasek et al., 1992; Lee et al., 1993; Minghetti and Levi, 1995; Pyo et al., 1997; Pyo et al., 1998). Recent studies indicate that microglial activation affects the progression of neurodegenerative disorders such as Alzheimer's disease and Parkinson's disease (GonzalezScarano and Baltuch, 1999; Vila et al., 2001). Such observations highlight the importance of understanding the processes regulating microglial activation.

In the injured brain, microglia can be activated by factors released from damaged cells and also by factors that infiltrate from the blood due to breakdown of the blood brain barrier. The glycospingolipid gangliosides are particularly rich in the neuronal membrane (Derry and Wolfe, 1967), which can be released from damaged neurons into the extracellular space. Previously, we reported that gangliosides induce expression of inflammatory mediators such as TNF- $\alpha$, iNOS and COX-2 in microglia (Pyo et al., 1999a; Kim et al., 2002). Blood plasma proteins were found to participate in the activation of microglia; thrombin and plasminogen induce expression of inflammatory mediators in microglia (Ryu et al., 2000; Choi et al., 2003; Min et al., 2003).

Many studies have been reported on the signaling pathways involved in microglial activation. Signaling molecules known to mediate activation by compounds such as lipopolysaccharide, gangliosides and thrombin include mitogen-activated protein kinase (MAPK), phospholipase $\mathrm{C}$, protein kinase $\mathrm{C}$ and NF-kB (Pyo et al., 1998; Pyo et al., 1999a; Ryu et al., 2000). The role of protein kinase $A(P K A)$ in microglial activation has not been established. In this study, we examined the involvement of PKA in microglial activation induced by plasminogen and gangliosides.

\section{Materials and Methods}

Cell culture

Primary microglia were cultured from the cerebral 
cortices of 1-3 day-old Sprague Dawley rats as previously described (Giulian et al., 1986; Pyo et al., 1998). Briefly, cortices were triturated into single cells in minimal essential media (Sigma, St. Louise, MO) containing $10 \%$ fetal bovine serum (Hyclone, Logan, UT) and seeded into $75 \mathrm{~cm}^{2}$ T-flasks $(0.5$ hemisphere/flask). Two weeks later microglia were detached from flasks by mild shaking and applied to a nylon mesh to remove astrocyte and cell clumps. Microglia were seeded into plates or dishes and medium was replaced after one hour in order to remove unattached cells. The BV2 immortalized murine microglial cell line was provided by Dr. E. J. Choi (Korea University). BV2 cells were constructed by infecting primary microglia with a v-raf/v-myc oncogene-carrying retrovirus $(\mathrm{J} 2)$, and show most morphological, phenotypical and functional properties of freshly isolated microglia (Blasi et al., 1990). BV2 cells were cultured in Dulbecco's Modified Eagle Medium (Gibco, Grand Island, NY) supplemented with $5 \%$ fetal bovine serum (Hyclone).

\section{Reverse transcription polymerase chain reaction (RT-PCR)}

Total RNA was isolated using RNAzol ${ }^{T M}$ B (TELTEST, Inc., Friendwood, TX), and cDNA was prepared using reverse transcriptase that originated from Avian Myeloblastosis Virus (TaKaRa, Otsu, Japan) according to the manufacturer's instructions. The sequences of PCR primers used for IL-1 $\beta$, TNF- $\alpha$, iNOS, GAPDH and actin gene amplifications are shown in Table 1.

\section{Protein kinase $A$ activity assay}

Cells were washed twice with cold phosphate-buffered saline, and then lysed in ice-cold lysis buffer $(50 \mathrm{mM}$ Tris- $\mathrm{HCl}, 0.1 \%$ Triton $\mathrm{X}-100)$ containing protease inhibitors $(2 \mathrm{mM}$ phenylmethylsulfonyl fluoride, $100 \mu \mathrm{g} /$ $\mathrm{ml}$ leupeptin, $10 \mu \mathrm{g} / \mathrm{ml}$ pepstatin, $1 \mu \mathrm{g} / \mathrm{ml}$ aprotinin, $2 \mathrm{mM}$ EDTA). Lysates were incubated on ice for 20 $\mathrm{min}$, then centrifuged at $10,000 \mathrm{~g}$ at $4^{\circ} \mathrm{C}$ for $20 \mathrm{~min}$, after which the supernatant was collected for assay. The assay mixture contained $5 \mu \mathrm{g}$ supernatant protein, $50 \mathrm{mM}$ Tris- $\mathrm{HCl}, 1 \mathrm{mM}$ DTT, $10 \mathrm{mM} \mathrm{MgCl}, 30$ $\mu \mathrm{M}$ kemptide (PKA substrate, Calbiochem, La Jolla, CA), $25 \mathrm{mM} \beta$-glycerophosphate and $2 \mu \mathrm{Ci}\left[\gamma^{32} \mathrm{P}\right]-$ ATP. Negative and positive control incubations contained $10 \mu \mathrm{M}$ PKI (a specific PKA inhibitor) and $5 \mu \mathrm{M}$ CAMP, respectively. After $5 \mathrm{~min}$ incubation, the reaction mixtures were spotted onto phosphocellulose paper, the paper was then washed twice with $1 \%$ phosphoric acid and once in $100 \%$ ethanol. The radioactivity associated with paper-bound phosphorylated peptide was counted using a liquid scintillation counter.

\section{Measurement of NF- $\mathrm{KB}$ and CREB Activation by electrophoresis mobility shift assay (EMSA)}

EMSA was carried out as previously described (Pier et al., 1981; Ryu et al., 2000). Briefly, BV2 $\left(5 \times 10^{5}\right.$ cells) were harvested and incubated on ice for 15 $\mathrm{min}$ in $900 \mu \mathrm{l}$ of a hypotonic solution [10 mM HEPES, $\mathrm{pH} 7.9,10 \mathrm{mM} \mathrm{KCl}, 0.1 \mathrm{mM}$ EDTA, $0.1 \mathrm{mM}$ EGTA, $1 \mathrm{mM}$ dithiothreitol (DTT), $0.5 \mathrm{mM}$ phenylmethylsulfonylfluoride (PMSF)] containing $0.5 \%$ nonidet $\mathrm{P}-40$. Cells were centrifuged at $2,000 \mathrm{~g}$ for $10 \mathrm{~min}$ at $4^{\circ} \mathrm{C}$ and the pellet (nuclear fraction) was collected. The nuclear fraction was resuspended in a buffer containing $20 \mathrm{mM}$ HEPES, pH 7.9, 20\% glycerol, 0.4 $\mathrm{M} \mathrm{NaCl}, 1 \mathrm{mM}$ EDTA, $1 \mathrm{mM}$ EGTA, $1 \mathrm{mM}$ DTT and $1 \mathrm{mM} P M S F$, incubated on ice for $60 \mathrm{~min}$ with occasional gentle shaking, and then centrifuged at $10,000 \mathrm{~g}$ for $20 \mathrm{~min}$. The crude nuclear proteins in the supernatant were collected and stored at $-70^{\circ} \mathrm{C}$ until use in EMSA. Synthetic oligonucleotides (Santacruz, California, US) containing the NF-KB binding sequence (5'-AGTTGAGGGGAGTTTCCCAGGC-3' and 3'-TCAACTCCCCTGAAAGGGTCCG-5') and the CREB binding sequence (5'-AGAGATTGCCTGACGTCAGAGAGCTAG-3' and 3'-TATCTAACGGACTGCAGTCTCTCGATC-5') were end-labeled using Klenow fragment and $\left[\gamma_{-}^{32} \mathrm{P}\right]-\mathrm{dATP}$. The labeled DNA probe (approximately $0.2 \mathrm{ng}$ ) was incubated for 30 minutes with

Table 1. The sequences of IL-1 $\beta$, TNF- $\alpha$ iNOS, GAPDH and actin PCR primers.

\begin{tabular}{lll} 
& \multicolumn{1}{c}{ Sense } & \multicolumn{1}{c}{ Antisense } \\
\hline Rat IL-1 $\beta$ & 5'-TGATGTTCCCATTAGACAGC-3' & 5'-GAGGTGCTGATGTACCAGTT-3' \\
Rat TNF- $\alpha$ & 5'-TGATGTTCCCATTAGACAGC-3' & 5'-GAGGTGCTGATGTACCAGTT-3' \\
Rat iNOS & 5'-GCAGAATGTGACCATCATGG-3' & 5'-ACAACCTTGGTGTTGAAGGC-3' \\
Rat GAPDH & 5'-TCCCTCAAGATTGTCAGCAA-3' & 5'-AGATCCACAACGGATACATT-3' \\
Mouse IL-1 $\beta$ & 5'-GCAACTGTTCCTGACTC-3' & 5'-CTCGGAGCCTGTAGTGCA-3' \\
Mouse TNF- $\alpha$ & 5'-ATGAGCACAGAAAGCATGATC-3' & 5'-TACAGGCTTGTCACTCGATT-3' \\
Mouse iNOS & 5'-TCACTGGGACAGCACAGAAT-3' & 5'-TGTGTCTGCAGATGTGCTGA-3' \\
Mouse Actin & 5'-CATGTTTGAGACCTTCAACACCCC-3' & 5'-GCCATCTCCTGCTCGAGTCTAG-3'
\end{tabular}


$1 \mu \mathrm{g}$ nuclear protein in a reaction mixture containing $8.5 \mathrm{mM}$ EDTA, $8.5 \mathrm{mM}$ EGTA, $8 \%$ glycerol, $0.1 \mathrm{mM}$ $\mathrm{ZnSO}_{4}, 50 \mu \mathrm{g} / \mathrm{ml}$ poly (dl-dC), $1 \mathrm{mM}$ DTT, $0.3 \mathrm{mg} / \mathrm{ml}$ bovine serum albumin and $6 \mathrm{mM} \mathrm{MgCl}$. The reaction mixture was separated on an $8 \%$ polyacrylamide gel, after which the gel was dried and autoradiographed. To identify specific binding of labeled oligonucleotides to the nuclear protein, excess $(\times 20)$ unlabeled oligonucleotide was added to control incubations.

\section{Statistical analysis}

Data were analyzed using the Statistical Package for Social Sciences 8.0 (SPSS Inc., Chicago, IL).

\section{Results}

Protein kinase A (PKA) mediates plasminogeninduced microglial IL-1 $\beta$, TNF- $\alpha$ and iNOS mRNA expression

Previously, we found that plasminogen induces in- terleukin-1 $\beta$ (IL-1 $\beta$ ) and tumor necrosis factor- $\alpha$ (TNF$\alpha)$ mRNA expression in microglia (Min et al., 2003). To examine whether PKA mediates microglial activation, we investigated the effect of PKA inhibitors, KT5720 and $\mathrm{H} 89$, on plasminogen-induced IL-1 $\beta$, TNF- $\alpha$ and inducible nitric oxide synthase (iNOS) mRNA expression. We found that in primary cultured microglia, KT5720 and $\mathrm{H} 89$ significantly reduced plasminogen-induced IL-1 $\beta$ and TNF- $\alpha$ mRNA expression (Figure $1 \mathrm{~A})$. Similar results were obtained when using the BV2 mouse microglial cell line and KT5720 and $\mathrm{H} 89$ also reduced plasmignogen-induced iNOS mRNA expression (Figure 1B). Since PKA inhibitors reduced plasminogen-induced IL-1 $\beta$, TNF- $\alpha$ and iNOS mRNA expression, we investigated whether plasminogen activated PKA. PKA was activated within $10 \mathrm{~min}$ of plasminogen addition, and that activity reached a peak after $30 \mathrm{~min}$, after which it decreased (Figure 1C). These results suggest that plasminogen activated microglia via PKA-dependent pathways.
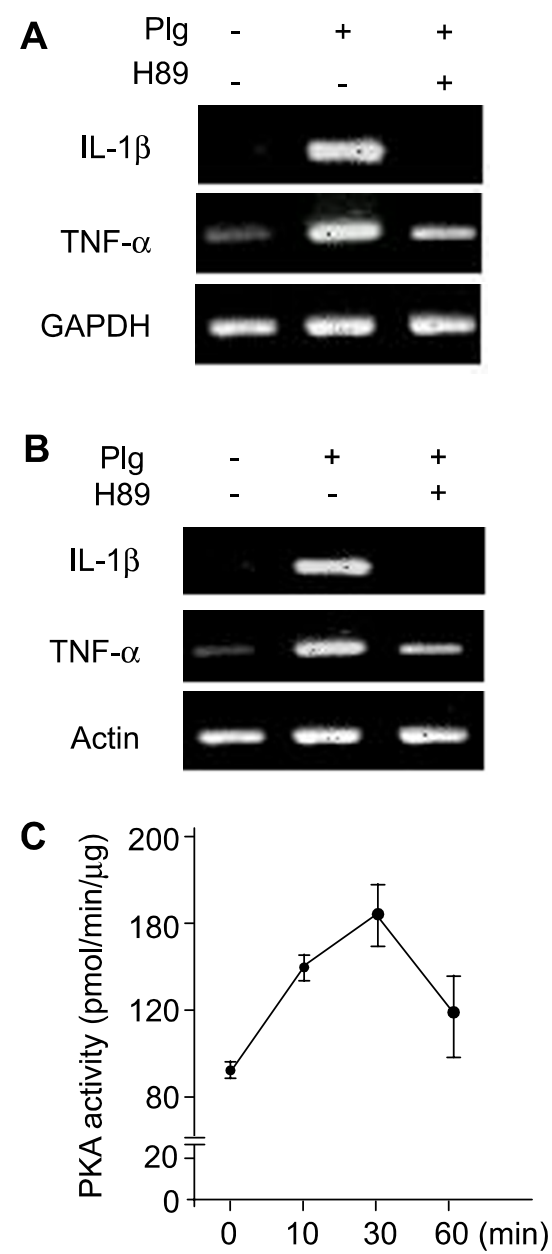
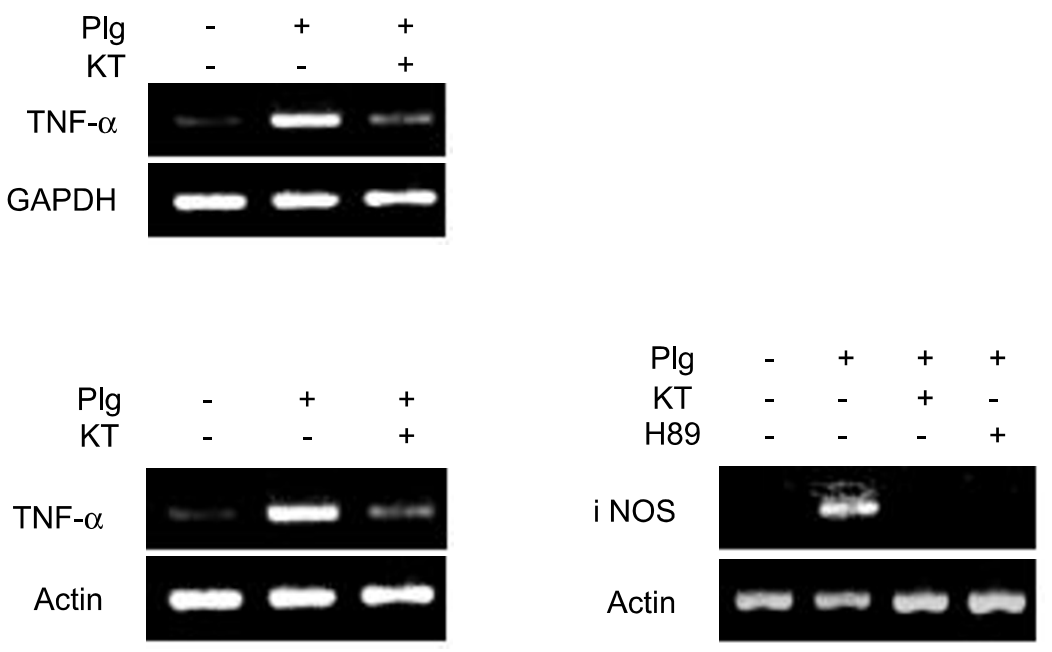

Fiqure 1. PKA mediates plasminogen-induced microalial activation. Primary microalia (A) and BV2 cells $(B)$ were treated with $40 \mu \mathrm{a} / \mathrm{ml}$ plasminogen (Pla) for $3 \mathrm{~h}$ in the absence or presence of the PKA inhibitors, $5 \mathrm{uM} \mathrm{H} 89$ and $250 \mathrm{nM}$ KT5720 (KT). IL-1B. TNF- $\alpha$ and iNOS mRNA expression was determined usina RT-PCR. (C) BV2 cells were treated with $40 \mathrm{ma} / \mathrm{ml}$ plasminogen for the indicated times and PKA activity was measured. Values represent the mean \pm SEM of three samples. Data are representatives of three independent experiments. 
A

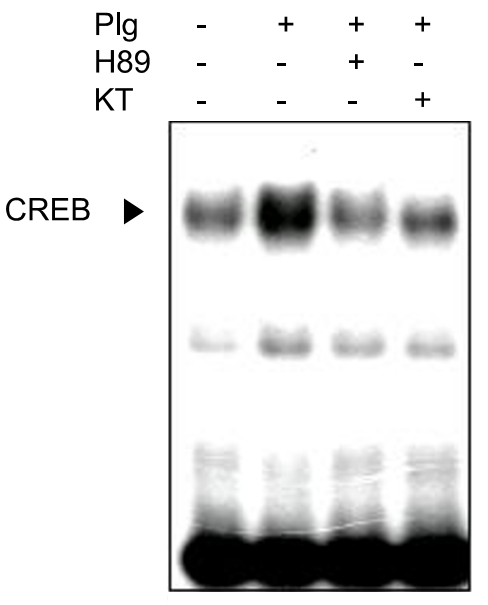

$1.00 \quad 2.220 .910 .94$

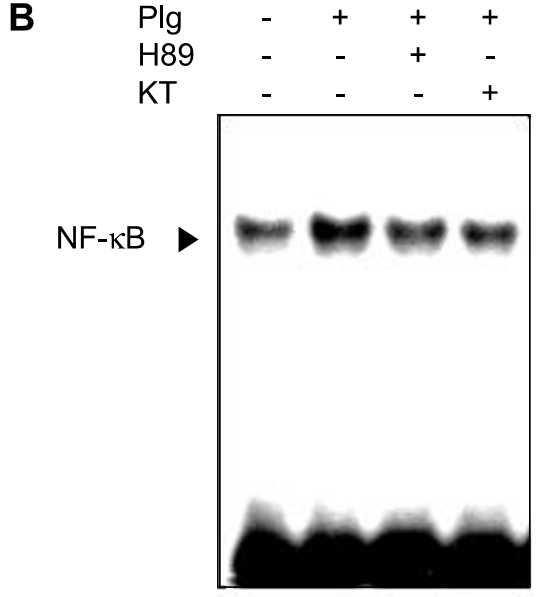

1.001 .791 .261 .09

Figure 2. PKA inhibitors reduce the DNA binding activity of CREB and NF-KB in plasminogen-treated microglia. BV2 cells were treated with $40 \mu \mathrm{g} / \mathrm{ml}$ plasminogen (Plg) for $5 \mathrm{~min}$ in the absence or presence of the PKA inhibitors, $5 \mu \mathrm{M}$ H89 or $250 \mathrm{nM}$ KT5720 (KT). Nuclear extracts were prepared and (A) CREB- and (B) NF-kB-specific oligonucleotide-protein complexes were detected using electrophoresis mobility shift assays. The values represent the normalized intensities of the CREB and NF-KB bands against intensities of control bands measured by Image Gauge technology. Data are representatives of three independent experiments.

\section{Plasminogen regulates DNA binding activities of CREB and NF-KB via protein kinase $A$}

cAMP response element (CRE) and NF-KB binding sites exist in the promoter regions of genes encoding IL-1 $\beta$, TNF- $\alpha$ and iNOS (Collart et al., 1990; Hiscott et al., 1993; Wong et al., 1996; Kinugawa et al., 1997; Stylianou and Saklatvala, 1998; Tsai et al., 2000; Chang et al., 2004). Furthermore, plasminogen increases the DNA binding activities of CRE binding protein (CREB) and NF-KB (Min et al., 2003). We examined whether PKA regulated CREB and NF-KB activation. We found that addition of KT5720 and H89 reduced plasminogen-stimulated $\mathrm{CREB}$ and NF-KB DNA binding activities (Figure 2). These results suggest that plasminogen increased CREB and NF-KB DNA binding activities through PKA-dependent pathways in microglia.

\section{PKA mediates gangliosides-induced microglial activation}

Although we have previously published that gangliosides activate microglia via diverse signaling pathways (Pyo et al., 1999a; Kim et al., 2002; Min et al., in press), the role of PKA in this activation has not been reported. We found that in primary cultured microglia, KT5720 and H89 reduced gangliosides-induced IL-1 $\beta$, TNF- $\alpha$ and iNOS mRNA expression. (Figure 3A). Furthermore, in BV2 cells, gangliosides activated PKA within $5 \mathrm{~min}$, and activity decreased to basal levels after $30 \mathrm{~min}$ (Figure 3B). We also found that gangliosides increased CREB binding activity within $5 \mathrm{~min}$. These results suggest that PKA positively regulates gangliosides-induced microglial activation.

\section{Discussion}

Previously, we reported that plasminogen and gangliosides activate microglia (Pyo et al., 1999a; Kim et al., 2002; Min et al., 2003; Min et al., In press). Microglial activation induced by these agents triggers diverse signal transduction pathways such as those involving reactive oxygen species, MAPK, PKC and JAK/STAT (Pyo et al., 1999a; Kim et al., 2002; Min et al., 2003; Min et al., In press). In the present study, we show that the signaling molecule PKA is also involved in positive regulation of microglial activation since plasminogen and gangliosides activated PKA, and PKA inhibitors reduced plasminogen- and gangliosides-induced IL-1 $\beta$, TNF- $\alpha$ and iNOS mRNA expression.

CAMP is a well-known second messenger that activates PKA. CAMP has been reported to either enhance or reduce iNOS expression depending on the stimuli and cell type. cAMP-elevating agents, including CAMP analogues, norepinephrine and prostaglandins, suppressed LPS-induced iNOS expression in rat microglia (Minghetti et al., 1997), Kupper cells (Mustafa and Olson, 1998) and hepatocytes (Smith et al., 1997). In contrast, cAMP induced iNOS expression in rat vascular smooth muscle cells and mesengial cells (Imai et al., 1994; Eberhardt et al., 1998). In human monocytes, murine astrocytes and rat cardiac myocytes, iNOS expression was induced by beta-endorphin and proinflammatory cytokines that increase 
A
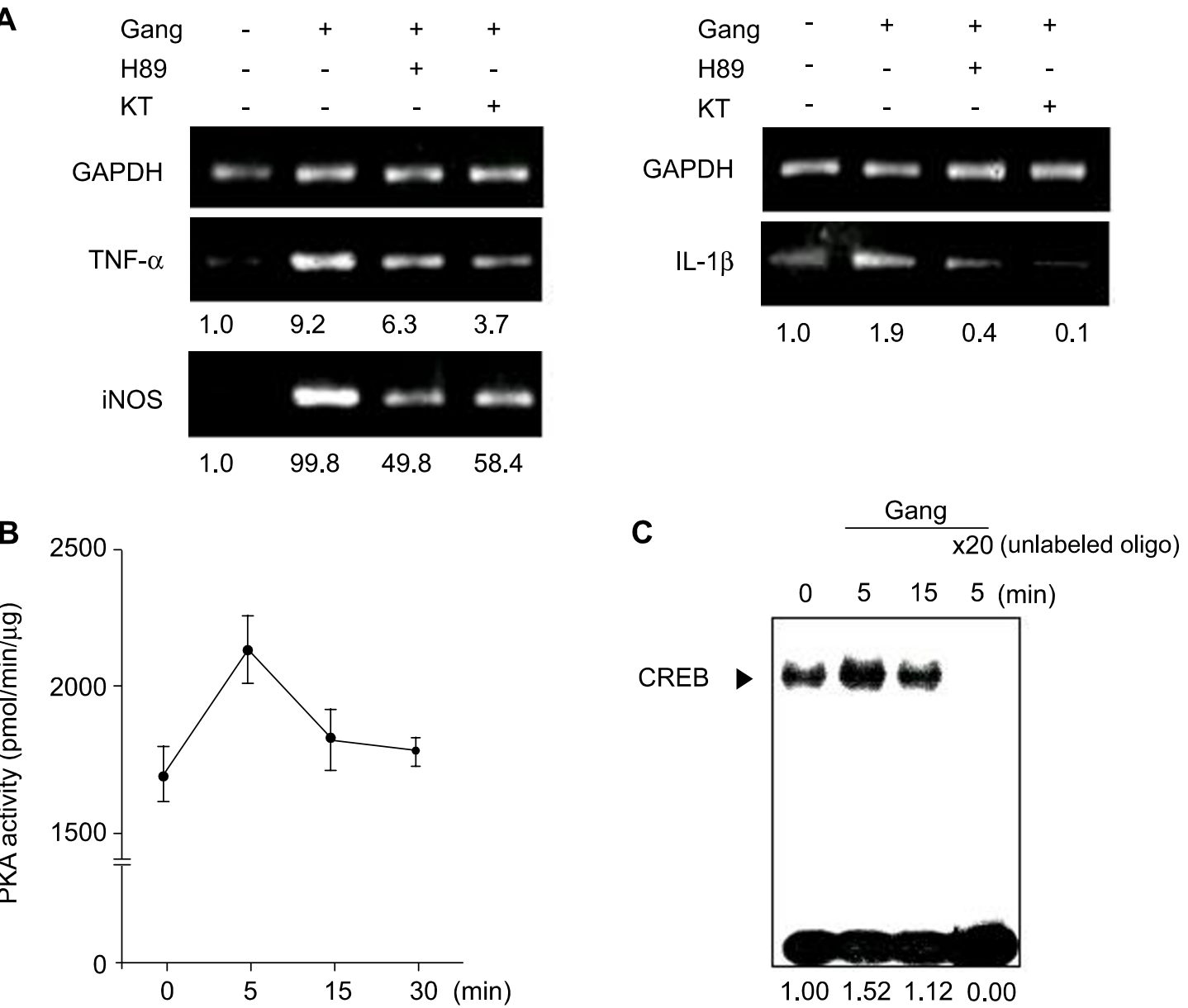

Figure 3. PKA mediates gangliosides-induced microglial activation. (A) Primary cultured microglia were treated with $50 \mu \mathrm{g} / \mathrm{ml}$ gangliosides (Gang) for $3 \mathrm{~h}$ in the absence or presence of $5 \mu \mathrm{M}$ H89 or $250 \mathrm{nM} \mathrm{KT5720} \mathrm{(KT).} \mathrm{TNF-} \alpha$, iNOS and IL-1 $\beta$ mRNA expression was determined using RT-PCR. (B) BV2 cells were treated with $50 \mu \mathrm{g} / \mathrm{ml}$ gangliosides for the indicated times and PKA activity measured. Values represent the mean \pm SEM of three samples. (C) BV2 cells were treated with $50 \mathrm{\mu g} / \mathrm{ml}$ gangliosides for the indicated times. Nuclear extracts were prepared and CREB-specific oligonucleotide-protein complexes were detected using electrophoresis mobility shift assays. The excess amount of unlabeled oligonucleotide was added to the reaction mixture to determine specific binding of labeled oligonucleotides to the nuclear protein $(\times 20)$. The values under the figures represent the normalized intensities of the TNF- $\alpha$, iNOS and IL-1 $\beta$ bands against intensities of GAPDH bands (A) or normalized intensities of CREB bands against intensity of the control band $(C)$ measured by Image Gauge technology. Data are representatives of three independent experiments.

intracellular cAMP levels (Oddis et al., 1996; Burgher et al., 1997; Aymerich et al., 1998). In microglia, we found that CAMP-elevating agents such as cholera toxin and dbcAMP enhanced beta-amyloid-(Pyo et al., 1999b) and LPS-induced NO release (data not shown). This differential effect of CAMP on iNOS expression may reflect different cell types and/or different stimulators. Furthermore, the duration and extent of intracellular CAMP increase and PKA activity may differentially regulate iNOS expression, even in the same cell type (Galea and Feinstein, 1999).

An increase in intracellular cAMP can induce the expression of many genes via PKA-mediated phosphorylation of transcription factors, such as the CAMP response element binding protein (CREB) (Chandra et al., 1995). The promoter regions of genes encoding IL-1 $\beta$, TNF- $\alpha$ and iNOS contain CREB binding sites (Stylianou and Saklatvala 1998; Galea and Feinstein, 1999; Tsai et al., 2000). Therefore, PKA may regulate IL-1 $\beta$, TNF- $\alpha$ and iNOS expression via CREB phosphorylation. In a previous study and this study, we showed that plasminogen and gangliosides enhanced CREB DNA binding activity (Figure $3 \mathrm{C}$, Min et al., 2003). Furthermore, PKA inhibitors reduced plasminogen-induced CREB binding activity (Figure 2A). Thus, we propose that CREB is a PKA target during plasminogen- and gangliosides-induced microglial activation.

NF- $\mathrm{KB}$ binding sites exist in the promoter regions of IL-1 $\beta$, TNF- $\alpha$ and iNOS genes (Collart et al., 1990; 
Hiscott et al., 1993; Xie et al., 1993; Chang et al., 2004). NF- $\kappa B$ activation may be regulated by PKA since in $\mathrm{J} 774$ macrophage-like cells, H89 inhibited LPS-induced NF-KB activation (Muroi and Suzuki, 1993). The results presented in the current study show that PKA inhibitors reduced NF-KB DNA binding activity in plasminogen-treated microglia (Figure 2B).

Extracellular-signal regulated kinase (ERK) may be another target of PKA. In PC12 cells, PKA is required for sustained activation of ERK (York et al., 1998). We previously reported that ERK mediates gangliosides-induced microglial activation since gangliosides activated ERK, and the ERK pathway inhibitor, PD98059, reduced gangliosides-induced NO release (Pyo et al., 1999a). In the present study, we found that both KT5720 and $\mathrm{H} 89$ reduced ERK activation in gangliosides-treated microglia (data not shown). In conclusion, the current results suggest that PKA is a positive regulator of microglial activation. Furthermore, the data suggest PKA exerts this control by acting as an upstream regulator of CREB and NF- $\mathrm{KB}$.

\section{Acknowledgement}

This work was supported by graduate school grants from the Ajou University School of Medicine, Korea. And Korea Science and Engineering Foundation (KOSEF) through the Brain Disease Research Center at Ajou University, and a grant (M103KV010006 03K2201 00650) from Brain Research Center of the 21st Centry Frontier Research Program funded by the Ministry of Science and Technology of Republic of Korea to E. Joe.

\section{References}

Aymerich MS, Bengoechea-Alonso MT, Lopez-Zabalza MJ, Santiago E, Lopez-Moratalla N. Inducible nitric oxide synthase (iNOS) expression in human monocytes triggered by beta-endorphin through an increase in CAMP. Biochem Biophys Res Commun 1998;245:717-21

Blasi E, Barluzzi R, Bocchini V, Mazzolla R, Bistoni F. Immortalization of murine microglial cells by a v-raf/v-myc carrying retrovirus. J Neuroimmunol 1990;27:229-37

Burgher KL, Heroux JA, Ringheim GE. Cyclic AMP potentiation of cytokine-induced nitric oxide synthase activity in a murine astrocyte cell line. Neurochem Int 1997;30:483-9

Chandra G, Cogswell JP, Miller LR, Godlevski MM, Stinnett SW, Noel SL, Kadwell SH, Kost TA, Gray JG. Cyclic AMP signaling pathways are important in IL-1 beta transcriptional regulation. J Immunol 1995;155:4535-43

Chang K, Lee SJ, Cheong I, Billiar TR, Chung HT, Han JA, Kwon YG, Ha KS, Kim YM. Nitric oxide suppresses inducible nitric oxide synthase expression by inhibiting post-translational modification of IkappaB. Exp Mol Med 2004;36:311-4
Choi SH, Joe EH, Kim SU, Jin BK. Thrombin-induced microglial activation produces degeneration of nigral dopaminergic neurons in vivo. J Neurosci 2003;23:5877-86

Collart MA, Baeuerle P, Vassalli P. Regulation of tumor necrosis factor alpha transcription in macrophages: involvement of four kappa B-like motifs and of constitutive and inducible forms of NF-kappa B. Mol Cell Biol 1990;10: 1498-506

Derry DM, Wolfe LS. Gangliosides in isolated neurons and glial cells. Science 1967;158:1450-2

Eberhardt W, Pluss C, Hummel R, Pfeilschifter J. Molecular mechanisms of inducible nitric oxide synthase gene expression by IL-1beta and CAMP in rat mesangial cells. J Immunol 1998;160:4961-9

Galea E, Feinstein DL. Regulation of the expression of the inflammatory nitric oxide synthase (NOS2) by cyclic AMP. FASEB J 1999;13:2125-37

Giulian D, Baker TJ, Shih LC, Lachman LB. Interleukin 1 of the central nervous system is produced by ameboid microglia. J Exp Med 1986;164:594-604

Giulian D, Johnson B, Krebs JF, George JK, Tapscott M. Microglial mitogens are produced in the developing and injured mammalian brain. J Cell Biol 1991;112:323-33

Gonzalez-Scarano F, Baltuch G. Microglia as mediators of inflammatory and degenerative diseases. Annu Rev Neurosci 1999;22:219-40

Hiscott J, Marois J, Garoufalis J, D'Addario M, Roulston A, Kwan I, Pepin N, Lacoste J, Nguyen H, Bensi G. Characterization of a functional NF-kappa $B$ site in the human interleukin 1 beta promoter: evidence for a positive autoregulatory loop. Mol Cell Biol 1993;13:6231-40

Imai $\mathrm{T}$, Hirata $\mathrm{Y}$, Kanno $\mathrm{K}$, Marumo $\mathrm{F}$. Induction of nitric oxide synthase by cyclic AMP in rat vascular smooth muscle cells. J Clin Invest 1994:93:543-9

Kim OS, Park EJ, Joe EH, Jou I. JAK-STAT signaling mediates gangliosides-induced inflammatory responses in brain microglial cells. J Biol Chem 2002;277:40594-601

Kinugawa K, Shimizu T, Yao A, Kohmoto O, Serizawa T, Takahashi T. Transcriptional regulation of inducible nitric oxide synthase in cultured neonatal rat cardiac myocytes. Circ Res 1997;81:911-21

Lee SC, Liu W, Dickson DW, Brosnan CF, Berman JW. Cytokine production by human fetal microglia and astrocytes. Differential induction by lipopolysaccharide and IL-1 beta. J Immunol 1993;150:2659-67

Min KJ, Jou I, Joe E. Plasminogen-induced IL-1beta and TNF-alpha production in microglia is regulated by reactive oxygen species. Biochem Biophys Res Commun 2003;312: 969-74

Min KJ, Pyo HK, Yang MS, Ji KA, Jou I, Joe E. Gangliosides activate microglia via protein kinase $C$ and NADPH oxidase. Glia 2004;In press

Minghetti L, Levi G. Induction of prostanoid biosynthesis by bacterial lipopolysaccharide and isoproterenol in rat microglial cultures. J Neurochem 1995;65:2690-8 
Minghetti L, Nicolini A, Polazzi E, Creminon C, Maclouf J, Levi G. Inducible nitric oxide synthase expression in activated rat microglial cultures is downregulated by exogenous prostaglandin E2 and by cyclooxygenase inhibitors. Glia 1997;19:152-60

Morioka T, Kalehua AN, Streit WJ. Characterization of microglial reaction after middle cerebral artery occlusion in rat brain. J Comp Neurol 1993;327:123-32

Muroi M, Suzuki T. Role of protein kinase A in LPS-induced activation of NF-kappa B proteins of a mouse macrophagelike cell line, J774. Cell Signal 1993;5:289-98

Mustafa SB, Olson MS. Expression of nitric-oxide synthase in rat Kupffer cells is regulated by cAMP. J Biol Chem 1998;273:5073-80

Oddis CV, Simmons RL, Hattler BG, Finkel MS. Protein kinase $A$ activation is required for IL-1-induced nitric oxide production by cardiac myocytes. Am J Physiol 1996;27: C429-C34

Pier GB, Markham RB, Eardley D. Correlation of the biologic responses of $\mathrm{C} 3 \mathrm{H} / \mathrm{HEJ}$ mice to endotoxin with the chemical and structural properties of the lipopolysaccharides from Pseudomonas aeruginosa and Escherichia coli. J Immunol $1981 ; 127: 184-91$

Pyo H, Chung S, Jou I, Gwag B, Joe EH. Expression and function of outward $\mathrm{K}+$ channels induced by lipopolysaccharide in microglia. Mol Cells 1997;7:610-4

Pyo $H$, Jou I, Jung S, Hong S, Joe EH. Mitogen-activated protein kinases activated by lipopolysaccharide and betaamyloid in cultured rat microglia. Neuroreport 1998;9:871-4

Pyo $H$, Joe E, Jung S, Lee SH, Jou I. Gangliosides activate cultured rat brain microglia. J Biol Chem 1999a;274:345849

Pyo $\mathrm{H}$, Jou $\mathrm{I}$, Jung $\mathrm{S}$, Joe $\mathrm{E}$. CAMP potentiates betaamyloid-induced nitric oxide release from microglia. Neuroreport 1999b;10:37-40

Ryu J, Pyo H, Jou I, Joe E. Thrombin induces NO release from cultured rat microglia via protein kinase $\mathrm{C}$, mitogen- activated protein kinase, and NF-kappa B. J Biol Chem 2000; 275:29955-9

Smith FS, Ceppi ED, Titheradge M.A. Inhibition of cytokineinduced inducible nitric oxide synthase expression by glucagon and cAMP in cultured hepatocytes. Biochem J 1997; $326: 187-92$

Stylianou E, Saklatvala J. Interleukin-1. Int J Biochem Cell Biol 1998;30:1075-9

Tsai EY, Falvo JV, Tsytsykova AV, Barczak AK, Reimold AM, Glimcher LH, Fenton MJ, Gordon DC, Dunn IF, Goldfeld $A E$. A lipopolysaccharide-specific enhancer complex involving Ets, Elk-1, Sp1, and CREB binding protein and p300 is recruited to the tumor necrosis factor alpha promoter in vivo. Mol Cell Biol 2000;20:6084-94

Vila M, Jackson-Lewis V, Guegan C, Wu DC, Teismann P, Choi DK, Tieu K, Przedborski S. The role of glial cells in Parkinson's disease. Curr Opin Neurol 2001;14:483-9

Wong HR, Finder JD, Wasserloos K, Lowenstein CJ, Geller DA, Billiar TR, Pitt BR, Davies P. Transcriptional regulation of iNOS by IL-1 beta in cultured rat pulmonary artery smooth muscle cells. Am J Physiol 1996;271:L166-L71

Woodroofe MN, Bellamy AS, Feldmann M, Davison AN, Cuzner ML. Immunocytochemical characterisation of the immune reaction in the central nervous system in multiple sclerosis. Possible role for microglia in lesion growth. J Neurol Sci 1986;74:135-52

Xie QW, Whisnant R, Nathan C. Promoter of the mouse gene encoding calcium-independent nitric oxide synthase confers inducibility by interferon gamma and bacterial lipopolysaccharide. J Exp Med 1993;177:1779-84

York RD, Yao H, Dillon T, Ellig CL, Eckert SP, McCleskey EW, Stork PJ. Rap1 mediates sustained MAP kinase activation induced by nerve growth factor. Nature 1998;392: $622-6$

Zielasek J, Tausch M, Toyka KV, Hartung HP. Production of nitrite by neonatal rat microglial cells/brain macrophages. Cell Immunol 1992;141:111-20 